\title{
Pre-Operational Business Planning: Program for Improving General Hospitals of Pademangan Class D be a Class $\mathrm{C}$
}

\author{
DR. Tantri Yanuar Rahmat Syah, SE., MSM ${ }^{1}$, DR. Rokiah Kusumapradja, MHA ${ }^{2}$, \\ Dr. Nofi Erni ${ }^{3}$, Ir, MM, Siti Rachmi ${ }^{4}$ \\ Thesis Adviser, Fakultas Ekonomi Dan Bisnis, Universitas Esa Unggul \\ Jalan Arjuna Utara No.9, RT.6/RW.2, Duri Kepa, Kebon Jeruk, Jakarta Barat, 11510 1,2,3 \\ College Student, Universitas Esa Unggul \\ Jalan Arjuna Utara No.9, RT.6/RW.2, Duri Kepa, Kebon Jeruk, Jakarta Barat, $11510^{4}$
}

\begin{abstract}
The purpose of the business planning of Pademangan Regional General Hospital is to improve the class from class D to class C. Hospital also implements social function, as well as considering the benefits because the class C hospital tariff is higher compared to class D hospital tariff. Considering the existing requirements, Pademangan Regional General Hospital can be upgraded to class C because it has been accredited in 2016. The number of human resources is appropriate with the support of the Regional Government and the Provincial Health Office of DKI Jakarta. Keywords: class improvement, SWOT analysis, Ministry of Health regulation number 56 of 2014.
\end{abstract}

\section{INTRODUCTION}

Hospital is a service organization that has specificity in terms of human resources and infrastructure facilities. Despite having slightly different characteristics with other industries, hospitals can be regarded as a health care industry that not only serves sick customers but also serves healthy customers who want to maintain their health.

Referring to the Law of the Republic of Indonesia No. 44 of 2009 on Hospital, that health service is the right of every person guaranteed in the 1945 Constitution, which must be implemented by efforts to improve the public health status as high as possible. The population of Republic Indonesia has reached more than 200 million people. Health issues should be placed as an important issue that must be a polemic to this day. For that purpose, government created a program based on the law to solve the problem that is called Jaminan Kesehatan Nasional (JKN) or National Health Insurance which can be enjoyed by all levels of society in Indonesia.

National Health Insurance was launched by the President of the Republic of Indonesia, Jokowi on January 1st 2014, held at Fatmawati General Hospital. This national health insurance program is one of the special programs that comes from the Indonesian government that will bring new solution for all levels of society. National Health Insurance has multi benefits both medically and non medically and benefits comprehensively in the form services provided are plenary ranging from preventive, promotive, curative, and rehabilitative. All services are not influenced by the cost of contributions from participants. Promotional and preventive activities are provided for individual health efforts.

With the initiation of the national health insurance system, the increase of patient visits in almost all hospitals are increasing, especially Regional General Hospital (RSUD) Class A and B. To avoid the patient accumulation, the governor of DKI Jakarta made PERGUB No 1024 of 2014 about the change of the function of the sub-district health center (puskesmas) to RSUD class D. At Jakarta, puskesmas that switch function to the RSUD are as much as fifteen, one of them is Pademangan puskesmas. RSUD D class began operating on 6 April 2015. In addition to the governor's regulation also the Ministry of Health Regulation number 71 of 2013 on a tiered referral system.

RSUD Pademangan stands on the $2790 \mathrm{~m} 2$ ground area and four-story building with a building area of $2636 \mathrm{~m} 2$. RSUD Pademangan is located on the Budi Mulia no. 2 Street District Pademangan Barat, North Jakarta. In the district of Pademangan, there are three sub-districts of West Pademangan, East Pademangan and Ancol, with a total population of about 162,957 people. Average residents of Pademangan are in lower-middle class economic society. The largest population is in the western village. The location of RSUD is very strategic in the middle of the settlement of residents and highway.

In Pademangan sub-district there is no hospital, either government or private. This becomes a business opportunity where patients who come apart from the local population can also encompass the workers who are in the offices around. 


\section{International Advanced Research Journal in Science, Engineering and Technology}

Vol. 5, Issue 11, November 2018

RSUD Pademangan also works closely with the nearest puskesmas, clinics, private practices, and Persada Hospital, Pertamina Hospital, etc.

\section{METHODOLOGY}

Pademangan Regional General Hospital Class D will be upgraded to class C, considering the increase in the number of patients, either outpatients and inpatients. In terms of tariffs, class C hospitals are higher than class D. Apart from these, Pademangan hospital has the strength that can be seen in the SWOT analysis. These strengths include qualified professionals, fast and friendly service, accredited since 2016, strategic and reachable location, and competitive rates. The existing opportunities are the density of the population which are in the middle-lower class, the government's support in hospital financing, the inter-hospital cooperation with BPJS, the location of the hospital adjacent to the companies and Ancol Amusement Park, far distance to other hospital, and the support of the North Jakarta SubDepartment of Health for facilitation of referrals from puskesmas.

SWOT Analysis table

\begin{tabular}{|r|l|c|c|c|}
\hline NO & \multicolumn{1}{|c|}{ STRENGTH } & Percentage & Rank & Score \\
\hline \hline 1 & Qualified medical personnels & 0,25 & 4 & 1 \\
\hline \hline 2 & Fast and friendly service & 0,05 & 4 & 0,2 \\
\hline 3 & $\begin{array}{l}\text { Having accreditation of Hospital Special Program } \\
\text { terakreditasi Program Khusus Rumah Sakit }\end{array}$ & 0,05 & 4 & 0,2 \\
\hline 4 & Strategic and reachable hospital location & 0,05 & 4 & 0,2 \\
\hline 5 & Competitive tariff & 0,1 & 4 & 0,4 \\
\hline \hline & \multicolumn{1}{|c|}{ Total } & $\mathbf{0 , 5}$ & $\mathbf{2 , 0 0}$ \\
\hline \hline
\end{tabular}

\begin{tabular}{|r|l|c|c|c|}
\hline NO & \multicolumn{1}{|c|}{ Weakness } & Percentage & Rank & Score \\
\hline \hline 1 & The lack of medical specialists & 0,2 & 2 & 0,4 \\
\hline 2 & Bed capacity of only 54 beds & 0,10 & 1 & 0,10 \\
\hline 3 & Available facilities have not meet the standards & 0,10 & 1 & 0,10 \\
\hline 4 & Hospital building has not meet class C hopital standard & 0,05 & 3 & 0,15 \\
\hline \hline 5 & Limited parking lots & 0,05 & 3 & 0,15 \\
\hline \hline \multicolumn{2}{r|}{ Jumlah } & $\mathbf{0 , 5}$ & & $\mathbf{0 , 9}$ \\
\hline
\end{tabular}

\begin{tabular}{|c|l|c|c|c|}
\hline NO & \multicolumn{1}{|c|}{ Opportunity } & Percentage & Rank & Score \\
\hline 1 & Population density & 0,1 & 4 & 0,4 \\
\hline 2 & Financial support from government & 0,05 & 4 & 0,2 \\
\hline 3 & \begin{tabular}{l} 
Adanya kerja sama antara Rumah Sakit dengan BPJS \\
\hline 4
\end{tabular} & $\begin{array}{l}\text { Hospital location near big companies ( PT Indofood, PT } \\
\text { Jaya Ancol, PT Ashahimas, Hotel berbintang) }\end{array}$ & 0,05 & 3 \\
\hline 5 & $\begin{array}{l}\text { Other government hospitals distance to Pademangan Clas } \\
\text { C General Hospital (10 km far) }\end{array}$ & 0,1 & 0,15 \\
\hline 6 & $\begin{array}{l}\text { Supports from North Jakarta Sub-Department of Health td } \\
\text { facilitate referral, either from puskesmas or class D } \\
\text { general hospital }\end{array}$ & 0,15 & 3 & 0,3 \\
\hline & \multicolumn{1}{|c|}{ Total } & $\mathbf{0 , 5}$ & 0,45 \\
\hline
\end{tabular}




\section{International Advanced Research Journal in Science, Engineering and Technology}

Vol. 5, Issue 11, November 2018

\begin{tabular}{|c|l|c|c|c|}
\hline NO & Threat & Percentage & Rank & Score \\
\hline \hline 1 & Same services in competitor hospital & 0,2 & 2 & 0,4 \\
\hline 2 & $\begin{array}{l}\text { The possibility of patients switching to other hospita } \\
\text { with more complete facilities }\end{array}$ & 0,2 & 2 & 0,4 \\
\hline 3 & Residential area susceptible to flood & 0,1 & 3 & 0,3 \\
\hline \hline Jumlah & $\mathbf{0 , 5}$ & & $\mathbf{1 , 1}$ \\
\hline
\end{tabular}

III.

ANALYST

\section{SWOT (Strenght, Weakness, Opportunity, Threat)}

In planning of the improving class, Pademangan General Hospital in addition to having the strength and business opportunities there are also weaknesses and threats. The weaknesses among others are the lack of human resources for specialist doctors, bed capacity, equipment facilities which are not yet fully equipped according to standard, the hospital building is not in accordance with C class standard, limited parking area.

To overcome the lack of specialist doctors, in 2018 will recruiting five specialist doctors who are internist, ENT, neurology, anesthesia, and lung specialists. Because that four cases are quite a lot. In 2018 with the addition of inpatient room so that the availability of the bed increased to 73 beds which the previously only 54 beds. For equipment from the year 2017 have been an increasing up to now.

The fifth weakness is the parking lot. The current condition can accommodate about 20 cars and 75 motorcycles, for expansion will use the existing land behind the generator set and if approved next to the hospital there is a aetra office that is no longer used, in regard to it administrative RSUD already gave a letter to the Head of North Jakarta Health Office.

The business threat of Pademangan General Hospital is the existence of a competitive hospital that has similar services, the more possibility of patients to switch to the more adequate hospitals, flood-prone residential neighborhoods. To avoid the transfer of patients to other hospitals, Pademangan Hospital has branding, friendly service, fast, and comfortable coupled with a professional workforce that always have been included in training both inside the hospital and held by outsiders.

\section{LICENSING}

Licensing to establish and permit the $\mathrm{C}$ class hospital operational is given by the head of regency / municipal government after receiving recommendation from health authority official at regency / city government. The establishment permit is granted to build a new building, or to change the function of the old building, while Pademangan Regional General Hospital has been established and has operated so that no permission is required. The required is a class decision letter issued by the Head of DKI Jakarta Provincial Health Office

Operational licenses are licenses granted to hospital managers to perform the health services. The operational permit is valid for a period of five years and may be extended as long as it meets the requirements, whereas for the Pademangan District General Hospital class D the permit has not been completed for five years, therefore it will be re-taken for classroom improvement. Requirements that have to be completed for operational licensing are: (1) hospital profile includes vision and mission, scope of activities, strategic plan, organizational structure, (2) selfassestment instrument contents according to hospital classification covering service, human resources, equipment, (3) blueprint, photo building, supporting facilities and infrastructure, (4) building use permit, (5) sustainable environmental management document, (6) human resources list, (7) list of medical and non medical equipment, (8) (10) medical and administrative documents, (10) administrative and management documents consisting of: ownership, hospital internal regulations (hospital by laws), medical committee, internal audit unit (SPI) ), license of health manpower, standard operating procedure of credential, medical staff, clinical assignment letter, certificate of calibration result of medical device.

In addition to the above requirements are attached letters from the Head of DKI Jakarta Provincial Health Office, feasibility study, strategic plan and a letter of application for change of operational permit. After the requirement is complete, the governor assigns the provincial health official to form a visitation team and regional association association then this team performs visas in the framework of assessment of hospital readiness and feasibility according to its classification.

The results of this assessment should be reported within a period of seven days. After that it was reported to the governor for an operational letter. Any hospital that has received an operating license must be registered and accredited by registration and accreditation as a requirement for extension of operational permits and classroom changes. 


\title{
International Advanced Research Journal in Science, Engineering and Technology
}

\author{
Vol. 5, Issue 11, November 2018
}

For wastewater treatment (IPAL) installation in 2018 the Pademangan District General Hospital will renovate the WWTP because the current capacity is not possible for the licensing of the hospital using consultant services.

\section{WASTE LICENSING PROCESS}

The licensing process for the wastewater treatment installation is submitted to the One Stop Office Integrated Service Office (PTSP) of the administrative city of North Jakarta according to the domicile. As for the requirements to manage the waste water disposal permit:

a. The identity of the applicant consists of KTP (Kartu Tanda Penduduk), Family Card (KK), Tax ID (Taxpayer Identification Number).

b. Letter of application in which there is a statement of truth and validity of documents on paper stamped Rp. 6000,

c. Environmental Documents UKL-UPL

d. Results of laboratory analysis Regional Environmental Management Agency (BPLHD)

Other licenses are licenses issued by the Head of the Nuclear Power Supervisory Agency, for radiological equipment.

Sipoc is a visual tool used to document business processes from beginning to end. Suppliers who provide goods and services needed by Pademangan Regional General Hospital in conducting its business can not be separated from the suppliers. Some suppliers such as suppliers for medical devices and medicines are required to select the suppliers of these hospitals are required to choose already in the e-catalog. Samples taken by suppliers of drugs, the need for medicines in public hospitals in the Provincial Government of DKI Jakarta implemented through the Health Department by way of an umbrella contract. The selection of providers through the Agency for Procurement of Goods Services at the City Hall. This model is intended to make the management of goods more transparent and if any inspection from the inspectorate does not differ between one hospital and other hospitals. But this raises obstacles for the hospital, because the suppliers must provide a large amount of drugs so that the drugs come to the hospital very long, especially if the purchase of these drugs using funds Regional Revenue Budget, because the procedure of funds disbursement of the Regional Revenue Budget also eat time, different if the use of the budget of the Regional Public Service Agency. So with the existence of this obstacle Pademangan Regional General Hospital in 2018 for the purchase of fast moving drugs will use the budget of the Regional Public Service Agency.

\section{SIPOC Analysis}

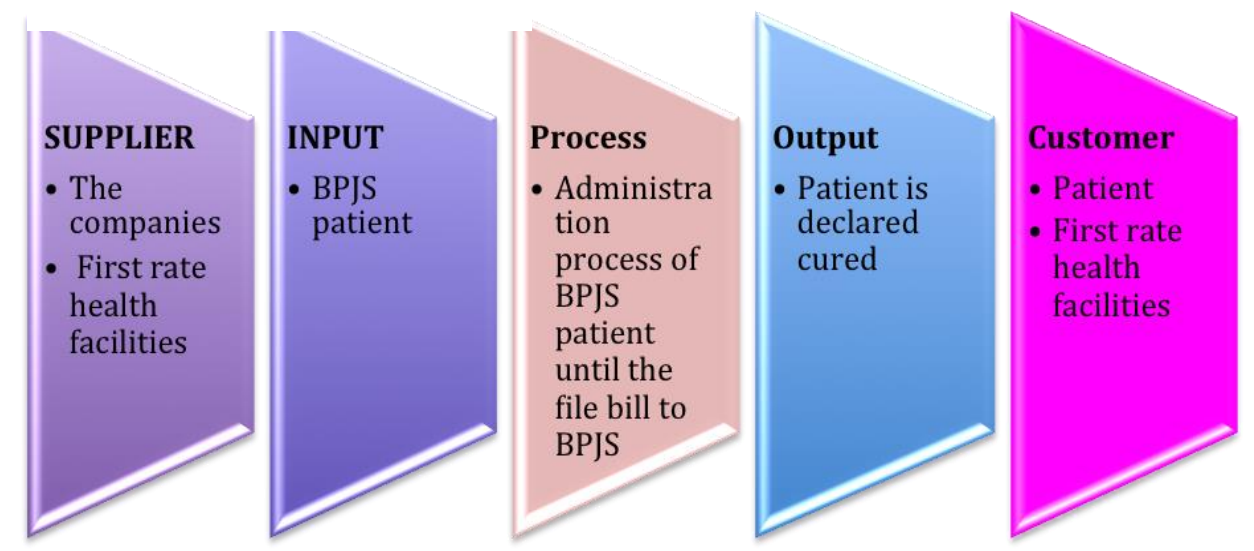

Fig.1.Analysis SIPOC

For the procurement of health equipment Pademangan District General Hospital using funds Regional Revenue Expenditure or the fund of the Regional Public Service Agency, while for laboratory equipment other than equipment owned by hospitals also in cooperation with PT. Indolab, Pramita and PT. SAM. Likewise for the procurement of office stationery, printed goods and sanitary equipment there are using funds from the Regional Revenue Budgets and funds of the Regional Public Service Agency. For patient's food logistics, procurement through Provider Procurement Agency together with Regional General Hospital and Puskesmas-Puskesmas in DKI Jakarta. For wet food by the provider delivered every three days while for dry materials delivered every two weeks, this food using funds from the Regional Public Service Agency. In addition to these suppliers, there are more puskesmas, clinics that are suppliers in terms of patient delivery.

Input in this case is to input data patient BPJS needed. Process (process) medical record officer records patient data, diagnosis, therapy up to the calculation of INA CBG's for bills to the office BPJS. Output here is the patient who treated 


\section{International Advanced Research Journal in Science, Engineering and Technology}

Vol. 5, Issue 11, November 2018

or treated has been stated there are improvements. As for customer of Pademangan Regional General Hospital are patients from health centers, clinics and doctors / midwives of practice.

\section{CONCLUSION}

To increase the class from D class hospital to C class. for Pademangan General Hospital, most of the requirements have been fulfilled, so it is expected that in 2019 where the community is obliged to become a participant of BPJS, Pademangan Regional General Hospital can be operated as a C class hospital, which became the referral center of firstrate health facilities around Pademangan and even among North Jakarta.

\section{REFERENCES}

[1]. Aditama Tjandra Yoga. 2002. Manajemen Administrasi Rumah Sakit. Jakarta:Universitas Indonesia

[2]. Sabarguna Boy S,Dr,dr,Mars. 2008. Manajemen Pelayanan Rumah SakitBerbasis Sistem Informasi. Jakarta: Sagung Seto

[3]. M. Jusuf Hanafiah dan Amri Amir, 1998, Etika dan Hukum Kesehatan, Medan ; EGC

[4]. Hartono Bambang,dr,M.Sc,MM. 2010. Manajemen Pemasaran Untuk Rumah Sakit. Jakarta: PT Rineka Cipta

[5]. Fred David. 2011.Implementing Strategies:Marketing Finance/Accounting, R\&D, and MIS Issues.New Jersey:Inc Pubilishing as Prentice Hall.

[6]. Republik Indonesia. 2014. Peraturan Menteri Kesehatan Nomor 56 Tentang Klasifikasi dan Perizinan Rumah Sakit Tahun 2014. Sekretariat Menteri Kesehatan. Jakarta

[7]. Republik Indoneia. 2009. Undang-Undang No. 44 Tahun 2009 Tentang Rumah Sakit. Sekretariat Negara. Jakarta 